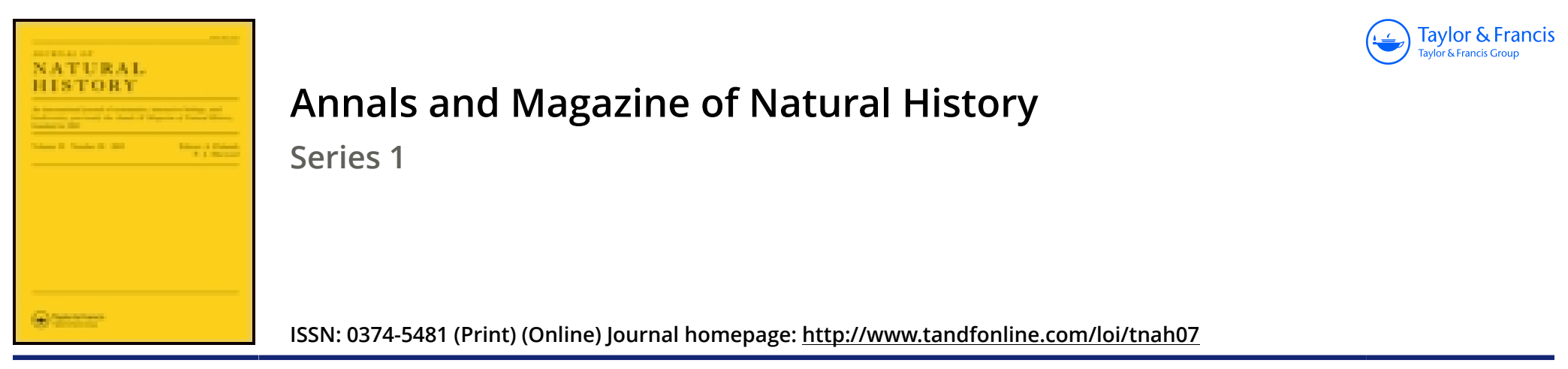

\title{
Regulus modestus, Gould, a British bird
}

\section{J. Hancock}

To cite this article: J. Hancock (1838) Regulus modestus, Gould, a British bird, Annals and Magazine of Natural History, 2:10, 310-311, DOI: 10.1080/00222933809496684

To link to this article: http://dx.doi.org/10.1080/00222933809496684

曲 Published online: 15 Mar 2010.

Submit your article to this journal 중

Q View related articles $₫$ 
nABITS OF SNAILS OR BLACK SLUGS (ARION ATER.).

Several instances have been adduced of the land Helices eating meat and other extraordinary substances, and I have often observed the garden snails (Helix aspersa) eating the paper of the posting bills from the walls of the environs of London after a shower, but I was not aware until the other day, when I was near Newcastle, that they would eat inorganic matter. But having met with a black slug, (Arion ater,) and for safety'placed it in a box with some sea-sand, just taken from the sea for the purpose of examining the fragments of animal matter which renders it luminous when trodden on in the dark, I was surprised on opening it to observe that the slug had been eating the sand, until its freces, which were first of a green vegetable colour, were entirely composed of pure sand, united together into their usual form by a little mucus. When first the slug was placed in the box, the irritation of the salt caused it to emit a quantity of mucus, but it very shortly became reconciled to its abode, and lived in it for several days, though the box was open; but at length escaped.-J. E. Gray.

REGULUS MODESTUS, GOULD, A BRITISA BIRD.

I beg to hand you a notice of a very scarce and interesting species of Regulus, which I shot on the banks near Hartley, on the coast of Northumberland, on the 26th of last September ; it corresponds exactly with Gould's Regulus modestus, a species so extremely rare, that he considers the individual from which he described as unique in the continental collections. The description of my bird, which will now entitle this species to a place in the British Fauna, is as follows:

Length, $4 \frac{1}{16}$ in.; breadth, $6 \frac{1}{2}$ in. ; length from the carpus to the end of the wing, $2 \frac{1}{16}$ in.; tail, $1 \frac{1}{16}$ in.; the bill from the gape to the tip nearly $\frac{7}{16}$ in., and from the tips of the feathers, which extend to the extremity of the nostrils, $\frac{1}{4}$ in.

The whole of the upper plumage a greenish yellow; on the centre of the crown of the head is a streak of paler; a light lemon-coloured streak extends over the eye from the base of the bill to the occiput; a short streak of the same colour passes beneath the eye, and a narrow band of dusky passes through the eye and reaches the termination of the auriculars. 'The under parts pale yellow; the ridge of the wing bright lemon colour; wing feathers dusky, edged with pale yellow, becoming broader on the secondaries; two conspicuous bands of lemcn colour cross the coverts; the wings reach to within $\frac{3}{4}$ in. of 
the end of the tail. Bill brown, with the under mandible paler at the base; mouth yellow; legs and toes brown with the under surface of the toes inclining to yellow; claws brown. Its manners, as far as I had an opportunity of observing them, were so like those of the golden-crested wren, that at first I mistook it for that species. It was continually in motion, flitting from place to place in search of insects on umbelliferous plants, and such other herbage as the bleak banks of the Northumberland coast affords: such a situation could not be at all suited to the habits of this species, and there can be little doubt that it had arrived at the coast previous to or immediately after its autumnal migrations.-J. НАхсоск, Newcastle-on-Tyne.

Note.-When Mr. Gould's figure appeared in the 'Birds of Europe,' we expressed an opinion that this might only prove a young bird of some of the other species, and we rejoice that an opportunity has now occurred of clearing this doubt. Mr. Hancock has stated to Mr. Selby that the covering of the nostrils in his specimen consists of various feathers and not of a single plumulet as in the other Reguli: this will afford a distinguishing mark, and will moreover destroy the importance of the structure as a generic character. We would recommend, however, that the nestling or first plumage of the Regulus aurocapillus and ignicapillus should still be examined. -EDir.

\section{METEOROLOGICAL OBSERVATIONS FOR OCTOBER 1838.}

Chiswick.-Oct. 1. Hazy. 2. Cloudy: fine. 3. Fine. 4. Very fine. 5. Hazy : fine. 6,7. Overcast. 8,9. Bleak and cold. 10. Cloudy. 11. Cloudy and fine. 12. Clear and cold : slight snow. 13. Clear: slowery : frosty at night. 14. Overcast : showery : frosty at night. 15, 16. Cloudy. 17, 18. Fine. 19. (ivercast: clear and fiue. 20. Raiu: overcast. 21-24. Cloudy and fine. 25. Foggy : clear at night. 26. Fine, 27. Cloudy : storny and wet at night. 28. Hazy : heavy rain : violent hurricane from s.w, during the night. 29. Clear and windy. 30. Fine. 31. Heavy rain.

Boston.-Oct. 1. Clondy. 2, 8. Fine. 4. Cloudy. 5. Fine. 6, 7. Cloudy. 8. Cloudy: rain p.u. $9-11$. Cloudy. 12. Stormy: suow P.M. 13. Fine: ice this morning one eighth of an inch thick. 14. Clondy: rain P.M. 15. Cloudy. 16. Cloudy : stormy P.M. 17, 18. Fine: stormy P.M. 19-21. Fine. 22.23. Cloudy. 2t. Cloudy : rain early A.M. 25. Cloudy. 26. Cloudy : rain early A.M. 27. Fine : stormy with rain P.M. 28. Fine: rain R.M. 29. Stormy : rain early arr. 30. Fine. 31. Cloudy.

Applegarth Manse, Dum/ries-shire.-Oct. 1, 2. Fine harvest days. S. Ditto, but cloudy : frosty p.ur. 4, 5. Very warm : frost rime. 6 . Warm : not a breatl of wind. 7. Mild day, but cloudy. 8. Fine harvest day. 9. Ditto, but threatening rain. 10. Still lowering and threatening rain. 11. High wind: slight shower. 12. Dry and cold. 13. Ditto: snow showers passing. 14. Wet all day. 15. Moist and stormy. 16. Wet all day. 17. Drying day. 18. Wet all day. 19. Drying again. 20. Clear and drying. 21, 22. Moist : showers P.Mr. 23. Fair A.M. : came on rain. 24. Showely. 25. Very wet P.M. 26. Rivers in flood : drying P.M. 27. Showery all day : flood again. 28. Hoar frost A.M. : fine e.M. 29. Partial showers. 30. Fine day: slight rains. 31. Fair : wet aftermoon. 